\title{
Financialized savings in public water governance: An illustrative case study in the arid American West
}

\author{
Christopher W. Gibson
}

California State University-Fullerton, USA

\begin{abstract}
How does financialization of the economy impact public governance of natural resources? One way includes a shift in how savings and cash accumulation are understood and practiced within public agencies. This article proffers that in the second half of the twentieth century, it became a taken-for-granted understanding that long-term savings should be held in financial investment accounts instead of traditional savings accounts. As a result of this, municipal organizations act as fiscally independent investors, marshaling economic resources to pursue strategic objectives that align with financialized institutional logics. Using a case study of the largest supplier of drinking water in the US, this article examines how the use of financial investments by a major public resource agency, Metropolitan Water District of Southern California, evolved since first establishing an investment policy in the 1940s. Today, this organization maintains investments worth over one billion dollars. Analysis of archival documents suggests that financial activities, even if yielding dwindling returns over time, are counted upon as a source of revenue, deployed to obtain favorable bond ratings, used for access to earmarked funds, and leveraged to acquire land in water-strategic locations. Considering the ubiquity of these financial practices among medium to large-sized municipal governing bodies, the results of this study are suggestive and generalizable across substantive governing fields and in other locations. Ultimately, this study shows that public governance agencies are intertwined with private capital flows, problematizing the oft-assumed distance between public and private actors. The article also interrogates the influence that financial markets have over of public policy, showing that elected governance officials engage in the commodification of money, encouraging the further commodification of environmental resources.
\end{abstract}

\section{Keywords}

Financialization, public policy, water, environmental governance, economic sociology 


\section{Introduction}

Financialization of the economy refers to the expansion of financial logics and undertakings into previously non-financial areas of activity. As the economy reoriented towards finance, infrastructural and municipal organizations found new opportunities to access financial capital due to stable and predictable revenue streams that could be securitized and traded (Leyshon and Thrift, 2007). A growing body of research examines the presence and consequences of financialization within organizations, both public and private, which manage water resources (Allen and Pryke, 2013; Bayliss, 2014; March and Purcell, 2014; Loftus and March, 2016; Schmidt and Matthews, 2018; Pryke and Allen, 2019; Furlong, 2020). We know that a key intersection of finance and water supply organizations is that the sector relies heavily on issuing bonded debt for capital financing (see Grigg, 2011 for a thorough description of "water handling' conceived as a business sector, including bond financing in Chapter 12). However, we know much less about the ways in which water suppliers also take on the role of financial investor, which I argue is an outcome of the expansion of financialized accumulative logics into public governance.

With an accumulation-centered view of economic change, Krippner (2005: 174) defines financialization as "a pattern of accumulation in which profits accrue primarily through financial channels rather than through trade and commodity production". Krippner highlights the challenge of observing economic changes in government stating, "there is no concept analogous to profits with which to gauge the 'accumulation' occurring in the public sector" (Krippner, 2005: 177). This study extends accumulation-centered financialization to the realm of municipal resource governance by examining how the use of financial investments came to supplant traditional savings accounts as a place for the agency to store cash and use it as a source of revenue. Considering that it is reasonable to assume, on the surface, that a public water agency generates revenue from selling water and collecting taxes, the fact that many agencies hold large - upwards of billions of dollars, as in this case study in financial investments warrants examination of accumulation-centered financialization under the constraints of the municipal organizational structure.

In this study, I examine the rise of financial investment within public water governance. Using a case study of a major water supply organization in California, the Metropolitan Water District of Southern California (MWD), I present evidence that in public governance the notion of saving and maintaining cash transformed into holding financial investments as the application of financialized accumulative logics evolved and expanded through the twentieth century. This article offers a theoretically oriented analysis that interrogates how, and why, a municipal water organization has come to embrace financial investments as a source of revenue and grow increasingly entangled with financial markets.

Governance organizations engage in a variety of financial endeavors seemingly outside the scope of their operational activities, often holding sizable accounts of money and investing on financial markets. This case study highlights that such organizations accumulate cash and investments and deploy financial transactions strategically in three ways. First, they engage in complicated financial earmarking arrangements to maximize access to funds, especially statebased discretionary funds. Second, they leverage their financial position in pursuit of favorable credit ratings. And third, they use access to financial capital to advance strategic objectives against perceived competitors. In this particular case study, we see the third dynamic illustrated by controversial land acquisition schemes that extend the urban water district's tentacles far into rural and agricultural settings. This can be seen as the latest financialized phase of water-based expansion and domination, which has deep historical roots (Worster, 
1992; Walton, 1993; Espeland, 1998) in the Western US. Viewed together, these actions show that public agencies behave similar to private investors and apply financial logics typically associated with private enterprise. This is made possible by a shift in thinking from the view that surplus assets should be held in savings accounts or redistributed through investment to the idea that savings should be accumulated and held in financial investments.

Research on the financialized landscape of modern public governance underscores the need to go beyond the public-private dichotomy (Bakker, 2010) and account for the ways in which public actors and organizations are entangled with private capital flows and behave in accordance with financialized logics. Historical examination shows that accumulation-oriented cash management policies emerge through a series of cap removals on investments, which created opportunities to further pursue financial aims and related objectives through a variety of strategies. The notion of financialized savings and the examples discussed in this study point to a unique type of accumulation that exists within the constraints of the municipal organizational model. In this mode of accumulation, we observe a blending of accumulation objectives (i.e., generating profits) with the deployment of a strong financial position in pursuit of operational goals (i.e., securing water rights).

This analysis examines quantitative and qualitative data from an in-depth historical case study of MWD, which is the largest water provider in the US. The services and infrastructure provided by MWD are "infrastructural preconditions for growth" (Kirkpatrick and Smith, 2011: 478) for much of the coastal basin in Southern California, from Ventura to San Diego. This case study is especially significant, empirically and theoretically, due to the scope and prominence of MWD. It has expansive economic reach, with over one billion dollars in annual revenue, and it consistently issues several billion dollars in municipal bond debt. In his historical account of MWD, Erie (2006: 9) states that, in 2002, MWD's service area was the eighth largest economy in the world with a gross product of $\$ 788$ billion. Its service area includes around 19 million people, serving the predominantly urban populations and industries of Los Angeles, San Diego and surrounding areas. As the main organizing body and provider of imported water for this very thirsty region, MWD is strategically positioned as an indispensable organization that is forced to negotiate the increasingly drought-prone conditions of the arid American West. Detailed methodological notes regarding MWD's archival data are provided in an appendix.

To understand how savings and cash accrual in municipal water governance became financialized and to examine its consequences, this article analyzes primary source archival data and proceeds in two parts - a theory-oriented description and an analysis of three key financial endeavors. First, I describe how MWD came to hold an investment portfolio worth over one billion dollars, explicating the role of the state in making this happen and the structural evolution of the organization with regards to policies on cash investments. Second, I examine how financial investments are deployed by the organization in complicated earmarking arrangements (Pacewicz, 2016), seeking to maximize access to state funding; used in presenting the organization's actions within dominant financial frameworks favored by credit rating agencies; and utilized in controversial land acquisitions in rural and agricultural settings. In the concluding remarks, I discuss the implications of financialized savings on the future of public municipal governance and the management of environmental resources.

Ultimately, the broad theoretical contribution of this study is to offer an understanding of how public governance, with regards to the provisioning of public goods, is shaped by private capital flows and financial markets. With that understanding, it is imperative to interrogate the internal contradictions between representing the public and administering municipal governance, on one hand, and pursuing a range of financial objectives, on the other. 


\section{Financialization, public governance and water}

Theorists long argued that modern society is largely defined by an irreversible rationalist order (Weber, 2002 [1905]). More recently, DiMaggio and Powell (1983) claim that rational bureaucratization drives organizations to behave similarly though not necessarily more efficiently. Regarding water organizations, Espeland (1998) details how diverging worldviews underpin conflicting notions of rationality with regards to how water resources are managed and infrastructure decisions made. Furthermore, Davis and Kim (2015) argue that social institutions are shaped by how finance plays an intermediary role between savers and borrowers. For example, in a financialized economy, mortgages and student loans are not held by banks until they are paid off as had been the case previously. Rather, they are securitized and resold, which affects the decision-making of the indebted households (Davis, 2011). Additionally, historical accounts show that governance and state capacity diminish when funds are raised on financial markets rather than through taxes and banks (Carruthers, 1996). Quinn (2019) details how the federal government, since the founding period, used credit markets as a political tool in multiple ways, including to avoid wealth redistribution while maintaining the appearance of economic opportunity. This history highlights that the use of financial instruments by government agencies, and the policies underpinning such acts, are proven to be consequential for a wide range of social outcomes. Considering the growing influence of financial markets throughout society, it is imperative to interrogate how public agencies that manage water resources organize themselves according to financial logics.

Scholars point to the 1970 s as a decade in which growth slowed dramatically and inflation increased, a dynamic that created a political shift in the 1980 s that embraced financial deregulation and paved the way for financialization to take hold (Crouch, 2009; Krippner, 2011; Streeck, 2011). These streams of literature point to the rise of finance in seemingly non-financial spheres of social and political activity as federal politics embraced financial deregulation through the 1980s. Accordingly, this examination of how a major municipal water agency used financial instruments throughout the second half of the twentieth century will likely reveal consequential trends associated with the increasing prominence and influence of financial markets.

With regards to the financialization of the water sector, research shows that financial interests view water revenues as a favorable investment due to the stability and durability of revenue stream and the structural monopolies that water organizations retain over their supplies (Allen and Pryke, 2013). Using the case of utility governance in Medellín, Colombia, Furlong (2020) demonstrates that individual users ultimately shoulder the burden of debt amassed by the utility company with particularly damaging consequences for low-income users. March and Purcell (2014) argue that the financialization of water delivery should be understood as a phenomenon involving the full network of infrastructure and services necessary for water delivery, and not only the product itself: water. In accordance with this suggestion, others show that the financialization of water goes beyond water revenues, demonstrating that the demands of financial actors, rather than the needs of a population or environment, wield substantial sway over infrastructural developments (Loftus and March, 2016; 2019). Among these examples is the Carlsbad desalination plant in San Diego, CA, a region within the service area of MWD, although this plant is operated by a different organization (Pryke and Allen, 2019).

Taking a more general global perspective, Bayliss (2014) argues that private financial interests exert powerful influence over water sector policy, shaping it in ways that serve global financial elites and corporations. Further, Schmidt and Matthews (2018) show how financial 
logics of risk calculation function to inform understandings of the global water-energy-foodclimate nexus in ways that undermine state-oriented development and privilege private financial accumulation through municipal sites. In these examples and the cases discussed above, the municipal organizations and utilities are positioned as sites of accumulation by largely dislocated and disembodied financial investors. An alternative, and under-examined, consideration is that municipal organizations and utilities are also financial actors that utilize access to financial capital for strategic investment purposes.

Studies in other empirical fields show that governance officials seek to maximize access to discretionary funds (Pacewicz, 2016) and that institutions outside the for-profit sector increasingly use finance to generate revenues as they simultaneously face pressures associated with increased costs to access debt financing (Eaton et al., 2016). Taking these notions together, this analysis seeks to examine the question: does MWD, as a large municipal water agency with significant financial resources, leverage its financial position to maximize access to discretionary funds, accumulate revenues, reduce costs and aggressively pursue long-term strategic objectives? Additionally, this study also considers what financialized governance structures mean for the broader field of public governance, including the many fiscally independent agencies that, despite shared objectives of provisioning public resources, must compete for scarce financial resources.

Studies show that the proliferation of financial markets has impacted urban living conditions, social policy and environmental concerns in a multitude of ways. For instance, the rise of tax increment financing instruments has made financial actors particularly influential in determining urban development trajectories (Pacewicz, 2013; 2016). The notion of the urban growth machine (Logan and Molotch, 1987) - a pro-growth coalition of private and public interests that exercises influence over urban policy - is complicated by a detailed accounting of the role of finance. For example, fiscal crises are shown to limit the financing options available to public works operations and, in turn, limit urban growth because infrastructural preconditions for growth are not realized (Kirkpatrick and Smith, 2011). Again, while debt financing is an extremely important topic relevant to the case study in this article, a comprehensive analysis of MWD's debt usage is beyond the scope of this study. Instead, by considering the agency's financial strategies as an investor - rather than a debtor - I illuminate the dynamics associated with maintaining cash assets in financial investment accounts, thereby exposing public funds to market risks and fiscal crises. In doing so, this study contributes to understanding what financialization means for water providers as well as tries to explicate the broader effects of financialization on the many public governance institutions that hold significant cash in savings and investments.

\section{MWD financial investments since 1948}

\section{MWD Board of Directors and financial investing}

This analysis of archival data begins with an examination of how and why the Board of Directors authorized the use of financial investments as a mode of storing accumulated cash. MWD entered financial markets slowly, according to board meeting documents, as a tool to generate supplemental funds. The earliest document in the MWD archives regarding the practice is dated May 14, 1948, which is a board meeting agreement authorizing the treasurer to invest 'surplus money' in US treasury notes. It was deemed necessary to cap the investments at two million dollars, and the board offered a glimpse into the rationale stating the following: 
The reason for making this recommendation is that at times we receive unusually heavy tax collections and the money may not be needed within one hundred days from the time of receipt. It is often impossible to have a Board meeting in time to authorize such purchase, and have the full 91-day period run after such authorization ... This recommendation would permit more flexibility in the investment of the District's monies that are not needed immediately and should result in the securing of more interest that under the present procedure. (Controller to Board of Directors, approved by board 5/14/1948)

This agreement effectively marks the beginning of the water district using financial investments as a form of savings. With this move, the agency now takes on a new role, as it temporarily redistributes public funds collected for use on local initiatives pertaining to water resources to federal government bonds. About one year later, in July of 1949, the controller of the agency authorized, in a one paragraph statement, an increase to the investment cap to \$3 million. This would begin a pattern of expanding the cap and the scope of investment practices.

Also, in 1949, but beyond the MWD boardroom, the State of California signaled its support for local agencies taking on outside investments. The state passed legislation on the investment of public funds by governing bodies with the Government Code Sections 53600 53610. The code states that local agencies and cities can invest funds defined as "moneys in a sinking fund or moneys in its treasury not required for the immediate needs of the local agency". It provides a list of acceptable investments which includes a variety of local, state, and federal bonds and treasury notes as well as "[c]ommercial paper of 'prime' quality of the highest ranking or the highest letter and number rating as provided for by a nationally recognized statistical rating organization". With some minimum standards and criteria to meet, the state essentially permitted local agencies to invest public funds in a wide range of public and private investments while institutionalizing the standards of private credit rating agencies that prioritize bondholder value over public benefits. Interestingly, in 1949 the new law was much less restrictive than MWD's internal policy on investments, which was maintained for many years.

In 1951, the MWD board approved an increase in the maximum investments from three to five million dollars and again in 1952, the cap was raised to seven million. In both of the letters the justification begins with, "Under ordinary circumstances, this maximum amount is sufficient. However ..." before the request for more money is made. In both instances, the rationale for the request is that the controller observed that additional sums of money are occasionally available for investment, and assumed that making these additional investments is in the best interest of the organization. Quickly, a pattern is established whereby MWD leadership continually seeks to invest greater sums and expand their revenue-seeking investment activities.

In the early 1960s requests were made and granted that saw greater flexibility extended to the controller and treasurer with regards to the types of bonds in which they could invest. Figure 1 shows the annual income generated by investments between 1960 and $2018 .{ }^{1}$ A 5year moving average helps to observe the broad trends in the time series. Investment income is a useful metric to observe the overall significance and scope of investment activities for MWD's revenues. Notably, the cap on how much could be applied to investments was raised to $\$ 40$ million by 1965 (approximately $\$ 300$ million adjusted to 2016 dollars equivalent), and in the same year the board agreed to remove the cap altogether. This resulted in a rapid increase in income from investments that can be seen in Figure 1. A brief yet highly significant board statement occurred in October 1969 when the MWD asserted that the treasurer would receive authority to invest surplus money 'pursuant to government code'. This means that MWD would shed the internal policies created to limit most investments to US Treasury bonds and instead 
allow their investment policy to be guided by the more economically liberal California Government Code Sections 53600. Among the restrictions that remained is a maturity limitation of no longer than 18 months from the date of purchase. However, this restriction was removed only a few months later by a board agreement in January 1970.

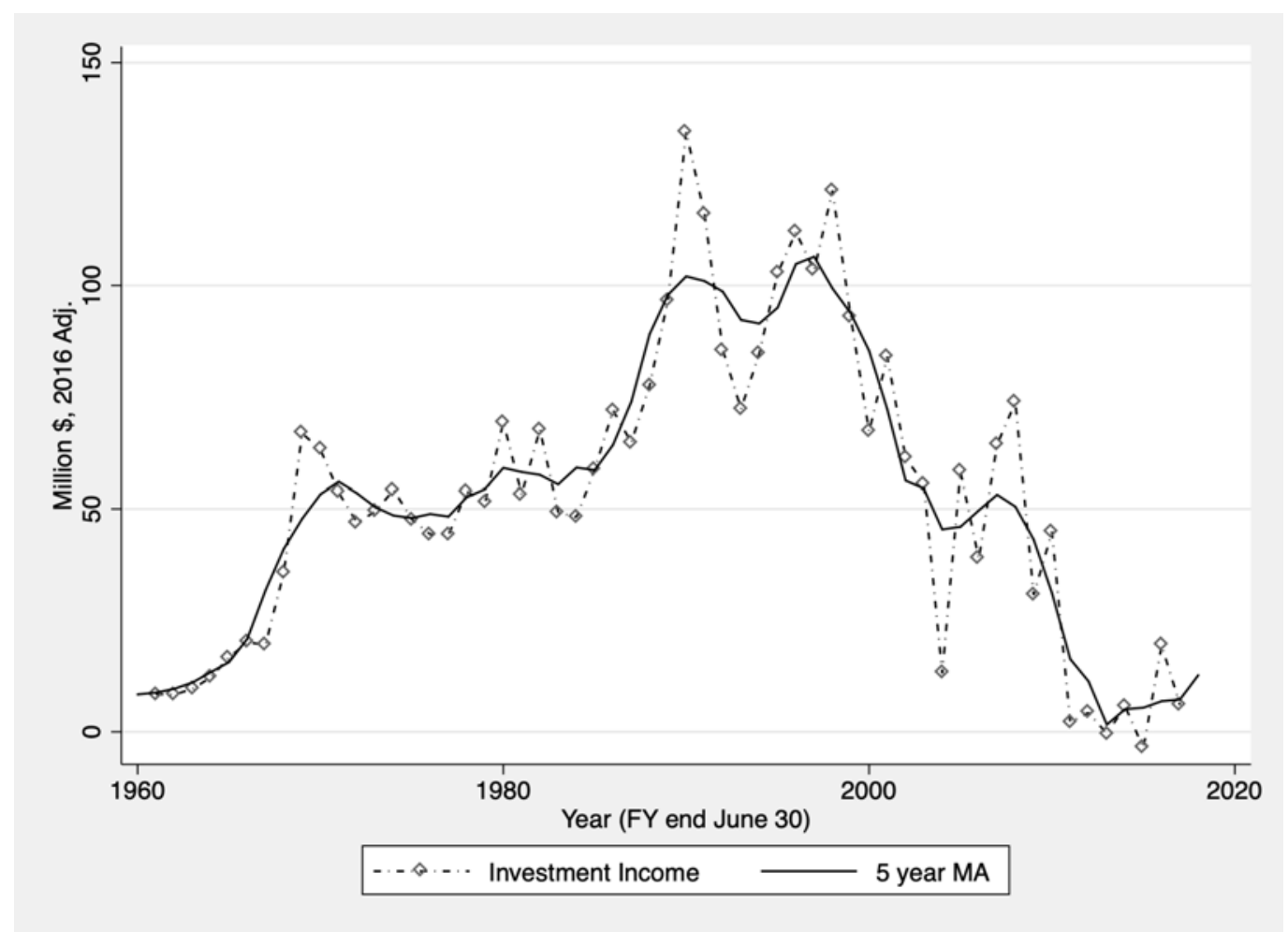

Figure 1. MWD's income from investments. Source: MWD Archives, 2018.

In 1977 , the state further institutionalized its support for this mode of investment by forming the Local Agency Investment Fund (LAIF) under the umbrella of the state treasurer's office. The LAIF centralized the investment of public funds on behalf of local agencies into a state-run pool. Any local agency could opt into the pool, which enabled smaller agencies with less organizational infrastructure to seek financial returns by contributing to the pool. This signals that the state government maintained a full-fledged embrace of the financialized savings of public funds.

The investment activities of MWD continued to grow in size following the removal of the $\$ 40$ million cap in 1970. After adjusting for inflation to the 2016 equivalent value, in 1992, the organization reported holding investments totaling $\$ 1.364$ billion with $\$ 86.9$ million in investment revenue and up to $\$ 2.105$ billion with $\$ 120.9$ million in investment revenue in 1998. The trend displayed on Figure 1 demonstrates that the 1990s were a period of above average investment income. With a cap on investment amounts removed, investment activity increased massively between 1970 and the 1990s.

These investments delivered substantial revenue gains to the agency in some years but not all. Through the process of financializing their cash savings, MWD becomes involved in speculative financial transactions worth billions, utilizing a range of investment instruments and, over time, conducting activities that resemble those of a financial institution in addition to a water district. What began in the 1940s as an unassuming endeavor to place unneeded funds in secure US Treasury bonds grew into an extensive and sophisticated investment 
operation with a billion-dollar portfolio and tens of millions in annual returns. With the growth of financial markets and a greater willingness to take part, the organization increasingly grew exposed to risk and financial volatility, something that can be observed in the wake of the 2008 financial crisis.

\section{The 2008 financial crisis}

The effects of the financial upheaval that occurred in 2008 are visible in MWD's annual investment income, as well as in other areas of MWD's accounting, including high and volatile interest rates on its own debt. ${ }^{2}$ As Figure 1 portrays, in 2008, MWD began to see increases after a generally downward trend in the 2000s but experienced a steep decline in investment returns between the end of the 2008 fiscal year and 2009, from $\$ 73.8$ million down $42 \%$ to $\$ 30.7$ million. After rebounding slightly to $\$ 40.6$ million in 2010 , MWD saw several years with single digit returns and losses in 2013 and 2015. These observations uphold the argument that financialized savings expose the municipality to market swings and volatility, which has the potential to destabilize long-term planning and even cause the agency to incur financial losses.

The sharp decline in income and two years of losses on such a sizable portfolio warrants concern about the exposure of public funds to the risks of capital markets. This is especially so in light of events like the 1994 Orange County default, the 2001 Enron scandal and the 2008 subprime mortgage crisis, to name a few cases that demonstrate the inability of credit rating agencies to validly predict and capture risk with their rating metrics. In official documents the committees and board of directors refer to MWD's investment portfolio as 'Cash and Investments' effectively considering investments to be synonymous with cash. This suggests the presence of a mindset that MWD's investments are a very safe place to store cash. The effects of the 2008 financial crisis, combined with the poor performance of the rating agencies preceding the sharp declines that marked the start of the recession, underscore the risks of viewing investment markets as a safe and secure place for a public agency to store funds.

\section{Financialized savings relative to investment income}

While Figure 1 tracks year-to-year investment income, Figure 2 shows the overall size of MWD's investment portfolio alongside investment income at three points in time, 1970, 1998, and 2017. To reduce the potential bias that may emerge if a given year deviates from the typical spending and savings trends, all values in Figure 2 represent 3-year moving averages. Figure 2 illustrates an outcome of the Board's decision to remove the $\$ 40$ million cap on investments in 1965 (approximately \$325 million adjusted to the 2016 equivalent). Within 5 years the portfolio grew significantly and was on a sharply increasing trajectory. A particularly important point is clarified by examining investment income alongside the growth of the portfolio size. As the agency expanded the amount invested, income from investments did not increase correspondingly - not even close. This demonstrates that the financialization of the MWD's savings practices cannot be explained by purely rationalist and instrumental economic objectives and that the ability of municipalities to capitalize on accumulation-centered strategies is highly variable. 


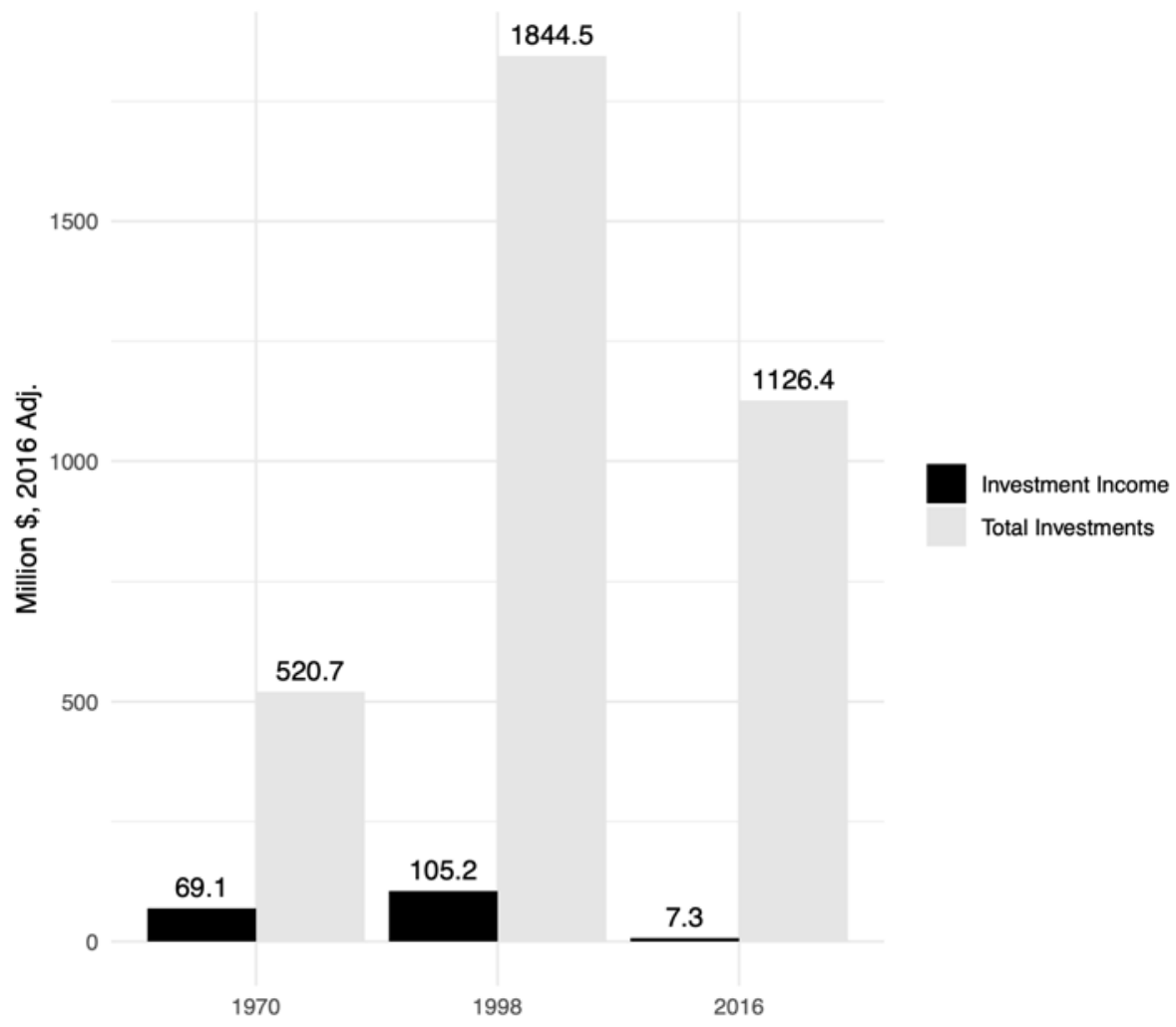

Figure 2. MWD's investment portfolio size and return. Source: MWD Archives, 2018. Note: All values are a 3-year moving average.

This quantitative examination of the agency's investment practices leads to two main findings: first, that portfolio size grew immensely after restrictions were removed, suggesting an embrace of financial logics within organizational leadership, and second, that greater financial investments have not generated proportional income returns, calling into question whether or not this is a financially instrumental activity and signaling a cause for concern about the exposure of public funds to market volatility and risks. The consequences of these factors will be explored in the discussion. Next, this study turns to examining what financialized savings mean for the organization by examining three ways in which MWD officials strategically deploy the organization's financial transactions and positioning to pursue a range of different objectives.

\section{Strategies associated with financialized savings}

\section{Earmarking and financial gymnastics}

A major dynamic related to the use of complex financial instruments and financialized savings has to do with the earmarking of funds (Pacewicz, 2016). The presence of earmarked funds highlights that not all the agency's money is equal despite the common assumption that money is a simple, morally neutral measure of value. In the case of the public water district, state and federal governments appropriate funds for use by regional agencies. Thus, funds can be earmarked by the state when offered to the district, and the district is required to adhere to certain conditions for receiving the earmarked money. In many cases, money is earmarked for construction projection and the water district categorizes these funds as 'restricted'.

Despite the conditionality of the earmarked funds, the district often benefits from receiving this restricted money because it has advantages like being tax and interest-free 
sources of income and loans. Earmarked funds are deployed strategically to perform various forms of 'financial gymnastics' in pursuit of maximizing access to capital and discretionary funds. I use the term financial gymnastics to refer to nontraditional financing schemes emphasizing the contortions and complexity of financial arrangements. Complicated and opaque financial schemes have become commonplace as accounting professionals engage in strategies of transferring money between accounts to create greater liquidity for the organization. As a result of accepting this as common practice, the potential consequences of such maneuvering go unexamined. While financial gymnastics and earmarking are not proof of financialization on their own, they are still crucial for pursuing and expanding financialized strategies in governance.

In one example, earmarking is expressed in the organization's two broad categories of restricted and unrestricted funds. A common condition attached to restricted funds is that the funds must be spent on construction projects that contribute to growth and development in a particular area. Although restricted in this way, these funds are advantageous for the organization because they are not taxed in ways that other sources of revenue are taxed. In seeking to maximize access to low-cost capital funds, MWD officials use its investment holdings to move money around to different categories while engaging in financial gymnastics to navigate earmarking restrictions. Without the organization's financial capacities, including the necessary accounting infrastructure as well as the strong credit ratings the expedite MWD's access to funding, such strategic arrangements would not be possible. This highlights how financialized savings function to serve the organization's aims beyond just returns on investments.

Board members and staff discussed an example of an opaque financial arrangement in a Finance and Insurance Committee meeting dated September 10, 2018, during which a board member asked about why MWD buys "municipals", referring to investments in municipal bonds. The fact that the board member was perplexed about the financial arrangement is indictive of how this is indeed a nontraditional and complicated financial structure, even in the eyes of the organization's own leadership. The staff member presenting on the financial details responded, "we borrow tax-free money and invest it in short term portfolio before we spend it on construction". The "tax-free money" refers to a specific allocation of funds by the State of California. In other words, the tax-free money from the state must be used on construction, but since the district can access this line of credit without cost, they are motivated to borrow it even if there are no construction needs at the time of borrowing. While that tax-free, but restricted, money is waiting to be used, it is placed in short-term, low risk investments, like municipals.

Remembering that MWD operates alongside thousands of other governance agencies competing for access to scarce funds, the state's redistribution efforts - that is, the efforts of the State of California to allocate state funds to governance districts where it is needed to benefit the public - are being reorganized by agencies according to financialized strategies. This has the potential to cause inefficiencies, from the perspective of the federal and statelevel distribution of resources, but MWD's financial maneuvering is internally strategic as they use tax-free restricted money for financial advantages without technically violating the restrictions placed on its use. An alternative arrangement would be to entirely circumvent the whole secondary investment process MWD engages in. The state could allow the restricted and tax-free money to immediately go to the municipalities that need it without repurposing it as investment capital. When MWD receives money and uses it as investment capital to buy the debt of other municipalities, interest costs are incurred by the debt issuer and all other parties associated with financial services. The ultimate benefactor of this reorganization of the state's 
financial distribution efforts is unapparent, but it is clear that the financial sector stands to gain by maximizing the volume of transactions, even if those transactions are circular or inefficient.

Scholars point out that, since the 1970s, consistent with neoliberal thinking (Hackworth, 2007), infrastructure projects have moved away from centralized interventions and federally funded endeavors, with regional municipalities taking on greater share of responsibilities (Mullin, 2009). This example illustrates an effect of the financialized decentralization of governance. In the financialized economy, municipal organizations compete against each other for access to low-cost funds and engage in sophisticated financial maneuvering to receive money even when it is not needed for the purpose intended by the state.

Financial arrangements like these are common in modern governance agencies, as organizations with sophisticated financial infrastructure and expertise use every lever at their disposal to maximize returns and access to discretionary funds. Being an active investor and embracing financial logics in organizational structures, allows MWD to access cash and credit as it competes with other municipalities for state and federal allocations under a highly decentralized funding system. This occurs in ways that are consistent with the politics of earmarking theory (Pacewicz, 2016). In the example of MWD's restricted funds, it is apparent that municipal actors will also seek restricted or non-discretionary funds and in so doing leverage financial arrangements to navigate earmarking restrictions.

\section{Investments as borrowing tools}

MWD, like nearly all regional governance agencies, relies on issuing debt with municipal bonds in order to raise funds. Every agency that issues debt receives ratings from the three major credit rating agencies, Fitch, Moody's and Standard \& Poor's. These ratings are highly consequential because they signal desirability to potential investors, effectively functioning as gatekeepers to financial capital (Hackworth, 2002; Sinclair, 2008). The credit rating signal stimulates and deters demand for debt, which in turn affects the interest rates and municipal agencies' ease of access to funds. Furthermore, credit ratings are also used in other institutional ways, including by state and federal bodies that judge the overall performance of municipal organizations and make decisions regarding the allocation of funds and resources. For instance, a water district with a better credit rating is considered by state officials as better equipped to receive grants and bond money from the state than a water district with a less favorable credit rating. In short, all water districts and other municipal agencies endeavor to receive favorable credit ratings.

Another function of the financialized savings strategy is that it provides a mechanism for the agency to amass money. The agency seeks positive credit ratings to secure the ability to easily sell their debt on the bond market at the lowest possible interest rate. This is evident in Fitch's rating rationale as seen in a report dated May 17, 2011: “The 'AA+/F1+' rating... reflects the liquidity provided by Metropolitan's cash and investments". Or, in another 2018 Fitch report: "Metropolitan's historically strong cash reserves (referring to "cash and investments') have provided a high degree of financial flexibility that has helped mitigate variable water transactions". This shows that holding investments is more than an added contribution to revenue; it is also a strategic tool for securing bond money and reducing interest rates.

Further, this structure encourages the organization to hoard surplus funds in investments, rather than reduce the cost of services or redistribute funds across other public goods. The approximate billion dollars in MWD's investment portfolio provides 'flexibility' (a 
term applied by rating agencies) and reduces the risk of MWD defaulting. As a public agency, one might question why MWD even has surplus money to use for financial investment, rather than redistribute money to the people in the service area through reduced rates. However, since these financial structures rely upon pleasing the financial gatekeepers, namely, credit rating agencies, they encourage the hoarding of surplus funds in investment reserves.

Moreover, as the credit rating reports demonstrate, the hoarding of surplus funds benefits the organization by mitigating 'variable water transactions'. Fluctuations in water sales is an ever-present issue for water districts that rely on revenue from water sales as an essential revenue stream. This is because consumers are often encouraged, or even forced, to reduce consumption during times of supply stress and drought. For instance, when Governor Brown declared a state of emergency in 2014, the State of California imposed mandatory cutbacks on water use for water districts throughout the state. Policies like these, while attempting to be environmentally sensitive and reasonable, are at odds with the financial structures in which the districts operate. This is because reduced consumption also reduces revenues, which in turn negatively impacts the long-term financial positioning of water districts. This is due to the fact that credit rating agencies penalize districts for things like “'variable water transitions' (Fitch Report, 2018) and other synonyms for selling less water even during times of drought. The effect of this financial arrangement and the municipality's reliance on bond financing encourages the water district to treat water as a revenuegenerating commodity rather than as a public good. And when the ability to sell the commodity is stifled, the agency falls back on financialized savings as a cushion that allows the status quo to continue until precipitation returns and regular sales resume.

\section{Land investments}

Investing in geographically strategic land acquisitions, outside of the service area, is not common practice for all water districts but it is observed with increasing frequency among the well-resourced water districts. While the acquisition of land is not a financialized saving in itself, it is a controversial outcome of municipal agencies growing politically powerful and financially formidable. The water district's ability to access substantial sums of capital with relative ease, both savings and borrowed money, enables this practice of reaping financial gain from land appreciation and rent collection. Many residents, businesses, advocacy groups, and commentators in California view deals like these with heavy skepticism. Situations of urban water interests using their large budgets and political strength to reach into the affairs of rural communities are quick to evoke contentious histories that include the drying of Owens Valley by an LA-based water organization (Walton, 1993; Reisner, 1993), ecological decline at Mono Lake (Mazaika, 2004), pollution of the Salton Sea (Sapozhnikova et al., 2004; Bradley and Yanega, 2018), and habitat degradation in the Bay Delta (Scoville, 2018). Some argue that the history of political power in the arid American West is a tale of autocratic domination through the control of water resources (Worster, 1992). This case lets us observe how institutional land grabs intersect with the financialization of the economy.

The urban consumption of resources is linked to negative impacts in rural environments. Nevertheless, MWD continues this cycle of urban control over rural resources and spaces by leveraging their financial advantages and economic resources. Two cases, one in the Palo Verde Valley in the South-East of California near the Colorado River and in the Bay Delta region in Northern California, are discussed in turn below. 


\section{Palo Verde Valley and river water rights}

About 170 miles from the eastern most boundary of MWD's service area, MWD used their deep cash and investment coffers to purchase tens of thousands of acres of agricultural land since 2001. At the time of this writing, the district is the largest landowner in the Palo Verde Valley near the California/Arizona border, where the Colorado River flows. MWD's acquisitions in Palo Verde have a clear purpose, to secure and increase its access to Colorado River water. The first purchase in the area came in 2001, when MWD paid \$41.4 million for 16,000 acres. As the new landlords of this farmland, MWD leased properties to farmers with the condition that it could require their tenants to fallow - eliminate water use and transfer the conserved water elsewhere - their farmlands upon request. In 2004, MWD struck a deal with Palo Verde Irrigation District (PVID) in which MWD would be able to pay farmers to fallow other previously productive farming lots - with farmers receiving annual payments totaling over \$100 million to increase water supplies transferred to MWD, helping them meet the demands of their urban service area. In 2015, MWD purchased another 12,782 acres of land in the area that was part of the PVID fallowing program for \$255.6 million, establishing MWD as the largest landowner in the valley.

The details of the 2015 purchase, as well as the earlier acquisition and fallowing deal, are summarized in a confidential board meeting memo obtained by a journalist through a public records request. This document is suggestive of MWD's key motivation. It explains that PVID is strategically important as it holds the most senior priority rights for the use of Colorado River water. Thus, purchasing land serviced by PVID allows MWD to benefit from the priority water rights. The memo states: "Land ownership provides Metropolitan with benefits that cannot be matched through alternative temporary arrangements". It also discusses that MWD's competition for buying the land includes farmers and argues that such owners who "permanently utilize the land for crop production will limit future opportunities for Metropolitan to provide financial incentives for temporary fallowing". Additionally, owning the land is said to reduce potential financial risk, should temporary fallowing deals require renegotiation. Thus, MWD is using its financial advantages to pursue a strategy that maximizes access to water resources for urban consumption while diminishing productive opportunities for rural and agricultural interests.

\section{Delta Islands and uncertain futures}

More recently, on July 18, 2016, MWD became a significant landowner in Northern California when they purchased about 20,369 acres of land, spanning 4 islands in the Bay Delta, for $\$ 196$ million. According to a September 2016 board document from the Finance and Insurance Committee, MWD used cash reserves to make the purchase and reimburse the cash reserves with debt. As stated in 2016, the plan included initially issuing taxable debt to refund the cash expenditure and later refunding it with tax-exempt debt after determining final land-usage and making the deal comply with IRS regulations. Similar to the response when MWD increased its footprint in Palo Verde, MWD's new neighbors in Northern California were extremely skeptical of the district's motives and plans. However, their intentions were uncertain then and remain so through to the time of this writing in 2020.

A November 2015 presentation during the Real Property and Asset Management Committee, as they prepared the organization for this purchase in the delta, offers a glimpse into the organization's decision-making. According to the presentation slides, the potential benefits of the land acquisition for MWD include water supply reliability by supporting water 
transfers, flood storage and salinity-outflow, emergency freshwater pathway and the California WaterFix tunnel project - a proposed infrastructure project to bolster MWD's conveyance system for imported water from Northern California. Another potential benefit includes environmental management with a focus on waterfowl habitat, fish food supplies, fish take reduction/turbidity management, greenhouse gas reduction, and other habitat restoration and mitigation. However, no further information was offered about how this purchase supports things like ecological habitat or greenhouse gas reduction. Based on discussions and presentations across the following months, including a Real Property and Asset Management Committee presentation in February 2017, MWD viewed real estate investment as particularly strategic for two key reasons. First, it lies in the path of the proposed California WaterFix tunnel project, and second, it lies along a proposed emergency pathway for moving freshwater to MWD's intakes in a natural disaster emergency, like an earthquake, a plausible scenario in this region.

This 2017 presentation also lists the current tenants and their existing rent payments, which range from $\$ 12,000$ per year for a house to $\$ 1$ million per year for larger tracts of land. The district essentially functions as an "absentee landlord", a characterization deemed accurate by MWD General Manager (GM), Jeffery Kightlinger at a public forum in Sacramento. ${ }^{3}$ During this forum, Kightlinger spoke about MWD's concerns regarding climate change and MWD's role in preparing for sea-level rise, major changes to weather patterns and reduced snowpack.

Our conclusion is that, you're going to see greater and greater saltwater intrusion moving in to the Delta. You're going to see all the impacts of bigger storm surges and all these things coming from climate change, more volatile conditions as snowpack turns in to rain. All of these things, to our mind, point to you having to do a lot of things. You have to be a lot of more local reliant as you can, you have to develop your groundwater basins. That's one of the things you have to do, do things locally. But you're going to have to build more robust infrastructure, meaning larger size facilities to capture peak flows, tunnels that go further north out of the area of seawater intrusion. To my mind, you're going to have to build that infrastructure that climate change is going to call for, or relocate millions of people, those are your options. (Kightlinger to community forum, 07/15/2016, emphasis added)

Kightlinger's remarks suggest that MWD sees their newly acquired lands in the delta as beneficial to MWD's aim of securing a consistent water supply for urban users in Southern California although exactly how is still unclear. One thing that is evident is that MWD's financialized savings strategies enabled a significant acquisition of land. An audacious plan like this is made attractive to MWD because it exists in a financial environment in which water sales, revenues, stable supplies, and dominance over natural cycles and climatological variabilities are the standard mode of operation.

To recap, I examined empirical evidence suggesting that MWD's financialized savings and associated financial position help it to navigate the politics of earmarking, amass large sums of stored money for financial flexibility, and leverage financial wealth in controversial land acquisitions. Viewed together, these three dynamics point to some of the potential outcomes of deploying financialized strategies for the management of public goods and natural resources.

\section{Discussion}

This article analyzed how a major municipal water agency engages in financial investment markets and pursues a financialized savings strategy that includes financial earmarking and 
controversial land acquisitions, mitigating the effects of climate variabilities on revenues at the behest of credit rating agencies. Additionally, I presented data to understand whether the structural and organizational shifts associated with financialization impacted public resource governance had similar effects on other realms of social and economic activity. This case study shows how a public agency - one initially formed to manage a fundamental natural resource - evolved to be a powerful organizational investor active in a range of accumulationcentered investment activities. We can observe a form of financial accumulation that is unique due to it occurring within the constraints of a municipal agency. Generally, studies of public agencies and financialization focus on the effects of debt burdens and accumulation at the hands of other financial interests. However, this study points to the fact that public agencies are also investors with their own unique accumulation practices that serve financial and nonfinancial objectives.

This research has empirical significance because MWD is the largest water provider in the nation, serving 19 million people, providing the preconditions for economic activity throughout Southern California and impacting hundreds of miles of watershed. Additionally, this research is potentially generalizable and theoretically relevant because the activities documented in this account of MWD occur to varying degrees in public governance organizations around the nation and world. For instance, a quick glance at the finances of nearly any medium-to-large water district, city government or other sub-national governing body will confirm the ubiquity of investing cash and assets akin to the methods used by MWD.

This research complicates the categories of public and private, and other similar manifestations of this duality including, 'privatized' versus 'nationalized' and 'commodity' versus 'public good'. Indeed, there is not a clear-cut division between the public and private sector in the contemporary financialized economy. The story of MWD illustrates how an ostensibly public organization invests capital on the private market, buys land and maintains financial portfolios similar to private financial actors. This study can help scholars consider how the activities of government agencies are shaped by private financial interests as well as theorize how governance bodies contend with competing interests, like the tensions emerging between democratic representation, environmental conservation, the pursuit of profit and other financial advantages.

Tracking the MWD's investment portfolio from midcentury to recent years shows that increasing financial investment has not generated proportionally larger returns. Additionally, the two years of losses in 2013 and 2015 underscore the risk of such financial exposure. The district's financialized savings are deployed for financial revenue in a way that is consistent with a reimagining of accumulation-centered financialization (Krippner, 2005). Furthermore, the district leverages its financialized savings to maintain positions favorable to credit rating agencies and bond investors (Hackworth, 2002; Sinclair, 2008; Poon, 2012; Carruthers, 2013). This financialized savings dynamic enables the district to pursue a variety of strategies including the examples detailed in this study. First, the district engages in the politics of earmarking (Pacewicz, 2016), maximizing access to discretionary funds. And second, the district uses its financial might to invest in controversial land acquisitions in rural and agricultural settings that secure resources for the district and its urban interests. The latter point emphasizes how financialized structures and access to capital are critical to extending the contentious history of rural dispossessions, class struggle and colonial expansion into the contemporary era (Worster, 1992; Walton, 1993; Espeland, 1998).

Additionally, finance is expensive and renders these public funds another domain for accumulation by capital investors and financial services providers. According to the fourth quarter 2017 financial performance evaluation, MWD pays $0.15 \%$ of assets in fees to third 
party asset management firms for financial services associated with the long-term portfolio. The estimated fee value for that year is $\$ 522,618 .{ }^{4}$ Since fees are assessed as a percent of assets, it is reasonable to conclude that financial services providers are keen to see the size of portfolios held by municipal agencies grow. Furthermore, costs associated with expansive financial engagements accrue, including to maintain internal financial personnel for portfolio management and to contract third-party firms for bond issuance and interest rate swaps. A complete analysis of how governance agencies navigate complex financial environments, including the role of financial service providers, is beyond the scope of this article. However, the explication of this is a promising avenue for future empirical research.

Considering that sociological research has yet to establish how financialization impacts public resource governance, it is necessary to constrain this analysis to a single organization to pursue rich detail and contextual depth. Cursory examination shows that financialized savings strategies are common to most governance agencies in the US. Therefore, theory development and empirical knowledge would benefit from comparative analysis across organizations to assess how variations in financialized savings - size of portfolio, active versus passive involvement, regulatory regimes - affect substantive governing outcomes, budget priorities and the provisioning of public goods. Further conceptual developments are also needed to help us understand how risk becomes spread and entangled across municipal agencies and the broader consequences of municipalities buying each other's debt.

Additionally, this study provides evidence that the decentralization of infrastructure development and governance since the 1970s produced an organizational landscape in which special districts and other fragmented policymaking authorities (Mullen, 2009) compete for various earmarked allocations from higher levels of government. By linking fragmentation to financial activities, this research extends prior work that demonstrates how fragmented governance in the water sector creates barriers to environmental resource conservation (Caniglia et al., 2016). In this competitive organizational landscape, water districts deploy financialized strategies to maximize access to funds as borrowers and investors incur costs and risks with each transaction. Furthermore, this study shows that in public water governance financial objectives motivate institutional actions alongside developmental and growth-oriented logics identified in studies of similar organizations (Hess et al., 2016).

Lastly, analysis that uncovers the causal links between financialized institutional logics and environmental governance and policy outcomes is critical to understanding how the environment has become financialized through public institutions. I contend that financial considerations, when given primacy to other governing concerns, have the potential to instill a circular financial pathology in governing institutions that can perpetuate environmental degradation and other social problems as agencies prioritize revenue-seeking activities over social expenditures. However, development of this causal mechanism is beyond the scope of the present paper. In this vein, another promising area for theoretical contributions is uncovering the institutional pathologies rooted in financialization. The modern municipal governance organization now resembles a hybrid of a democratic policy body administering public needs on one hand and a financial institution on the other. The consequences of this are not yet fully understood but observations of the largest municipal water provider in the US suggest that financialization, rather than commodification, may offer a more coherent explanation for the persistence of certain forms of ecological degradation and unsustainable consumption of natural resources. 


\section{Acknowledgements}

I offer deep gratitude to Nina Bandelj, David A. Smith, Evan Schofer, Valerie Olson, David A. Snow and Mike Antos for reading and discussing this work at various stages of development. I am grateful to the anonymous reviewers and the editor, Sandy Hager, for their thoughtful and constructive feedback. I am also appreciative for the forums provided by the Center for Organizational Research, the Society and Environment Reading Group and the Global Reading Group at UC Irvine. And lastly, I am also extremely grateful to the water agency directors, general managers and staff members who helped me learn about the complicated world of water resources management.

\section{Notes}

1. The Bureau of Labor Statistics' Consumer Price Index is used for all inflation adjustments.

2. The impacts of municipal bond debt in shaping water agency activities are analyzed in forthcoming research. A detailed discussion on debt is beyond the scope of this article, which focuses on accumulation-centered investments.

3. A video recording of the public forum is available online: <https://vimeo.com/174895102/>.

4. Figures located on page 37 of Fourth Quarter 2017 Investment Review, retrieved from MWD here: <http://www.mwdh2o.com/WhoWeAre/Management/Financial-Information>.

\section{Appendix}

With regards to data collection, financial matters fall under the domain of MWD's Finance and Insurance Committee. Thus, much of the qualitative data was gathered from publicly available documents pertaining to the activities of this committee, such as memos, board meeting letters, and presentation slides as well as archived video and audio streams of board meeting presentations.

Data on land and real estate acquisitions were collected from memos and presentation slides from MWD's Real Property and Asset Management Committee. All data were collected digitally from MWD's online database between 2018 and 2020 and in person during a visit to MWD's Los Angeles headquarters in 2018. Archival items for qualitative data were selected based on the identification of pivotal moments like the first board resolution on financial investments or meetings on major land acquisitions. Documents identified with relevant qualitative data were coded and analyzed with Atlas.TI. For this article, I built a quantitative dataset with data from 1960 to 2018, containing 12 variables, focusing specifically on investment portfolio size and investment income. The documents used for quantitative data gathering were Annual Reports, Treasurer Statements and Financial Reports.

Additionally, measures were taken to ensure as much precision as possible in quantitative data collection to account for ways that statistics and categories reported by MWD fluctuate over time. Due to the historical contingency of accounting practices, MWD policies, and other financial standards, the year-to-year data values should be understood as approximations rather than exact amounts. The statistics used for the analysis were purposefully chosen to ensure consistency and valid comparability over time. A list of key search phrases used for navigating the document archives is as follows: Surplus Money; Surplus Monies; Surplus Moneys; Investment; Investment Activity; Investment Activities; Investment Policy; Investment Policies; Investment Performance; Treasurer's Authority; Treasurer's Report; Treasurer's Monthly Report; Financial Report; Annual Report; Credit Rating; Credit Ratings; Delta; Delta Islands; Palo Verde; Blythe; and Real Property. 


\section{References}

Allen, J. and Pryke, M. (2013) Financializing household water: Thames Water, MEIF, and 'ring-fenced' politics. Cambridge Journal of Regions, Economy and Society, 6(3): 419-39.

Bakker, K.J. (2010) Privatizing Water: Governance Failure and the World's Urban Water Crisis. Ithaca, NY: Cornell University Press.

Bayliss, K. (2014) The financialization of water. Review of Radical Political Economics, 46(3): 292-307. Bradley, T.J. and Yanega, G.M. (2018) Salton Sea: Ecosystem in transition. Science, 359(6377): 754.

Caniglia, B., Frank, B., Kerner, B., and Mix, T.L. (2016) Water policy and governance networks: A pathway to enhance resilience toward climate change. Sociological Forum, 31: 828-45.

Carruthers, B.G. (1996) City of Capital: Politics and Markets in the English Financial Revolution. Princeton, NJ: Princeton University Press.

Carruthers, B.G. (2013). From uncertainty toward risk: The case of credit ratings. Socio-Economic Review, 11(3): 525-51.

Crouch, C. (2009) Privatized Keynesianism: An unacknowledged policy regime. The British Journal of Politics and International Relations, 11(3): 382-99.

Davis, G.F. (2011) Managed by the Markets: How Finance Reshaped America. Oxford: Oxford University Press.

DiMaggio, P.J. and Powell, W.W. (1983) The iron cage revisited: Institutional isomorphism and collective rationality in organizational fields. American Sociological Review, 48(2): 147-60.

Eaton, C., Habinek, J., Goldstein, A., Dioun, C., Santibáñez Godoy, D.G. and Osley-Thomas, R. (2016) The financialization of US higher education. Socio-Economic Review, 14(3): 507-35.

Erie, S.P. (2006). Beyond Chinatown: The Metropolitan Water District, Growth, and the Environment in Southern California. Stanford, CA: Stanford University Press.

Espeland, W.N. (1998) The Struggle for Water: Politics, Rationality, and Identity in the American Southwest. Chicago: University of Chicago Press.

Furlong, K. (2020) Trickle-down debt: Infrastructure, development, and financialisation, Medellín 19602013. Transactions of the Institute of British Geographers, 45(2): 406-19.

George, A.L. and Bennett, A. (2005) Case Studies and Theory Development in the Social Sciences. Cambridge, MA: MIT Press.

Grigg, N. (2011) Water Finance: Public Responsibilities and Private Opportunities. Hoboken, NJ: Wiley. Hackworth, J. (2002) Local autonomy, bond-rating agencies and neoliberal urbanism in the United States. International Journal of Urban and Regional Research, 26(4): 707-25.

Hackworth, J.R. (2007) The Neoliberal City: Governance, Ideology, and Development in American Urbanism. Ithaca, NY: Cornell University Press.

Hess, D.J., Wold, C.A., Hunter, E., Nay, J., Worland, S., Gilligan, J. and Hornberger, G.M. (2016) Drought, risk and institutional politics in the American Southwest. Sociological Forum, 31: 807-827.

Kirkpatrick, L.O. and Smith, M.P. (2011) The infrastructural limits to growth: Rethinking the urban growth machine in times of fiscal crisis. International Journal of Urban and Regional Research, 35(3): 477-503.

Krippner, G.R. (2005) The financialization of the American economy. Socio-Economic Review, 3(2): 173-208.

Krippner, G.R. (2011) Capitalizing on Crisis: The Political Origins of the Rise of Finance. Harvard, MA: Harvard University Press.

Loftus, A. and March, H. (2016) Financializing desalination: Rethinking the returns of big infrastructure. International Journal of Urban and Regional Research, 40(1): 46-61.

March, H. and Purcell, T. (2014) The muddy waters of financialisation and new accumulation strategies in the global water industry: The case of AGBAR. Geoforum, 53: 11-20. 
Mazaika, K. (2004) The Mono Lake Case: Shaking up the established powers. In: d'Estrée, T.P. and Colby, B.G. (eds) Braving the Currents. Boston, MA: Springer US, 71-105.

Mullin, M. (2009) Governing the Tap: Special District Governance and the New Local Politics of Water. Cambridge, MA: MIT Press.

Pacewicz, J. (2013) Tax increment financing, economic development professionals and the financialization of urban politics. Socio-Economic Review, 11(3): 413-40.

Pacewicz, J. (2016) The city as a fiscal derivative: Financialization, urban development, and the politics of earmarking. City \& Community, 15(3): 264-88.

Poon, M. (2012) Rating agencies. In: Cetina, K.K. and Preda, A. (eds.) The Oxford Handbook of the Sociology of Finance. Oxford: Oxford University Press.

Pryke, M. and Allen, J. (2019) Financialising urban water infrastructure: Extracting local value, distributing value globally. Urban Studies, 56(7): 1326-46.

Reisner, M. (1993) Cadillac Desert: The American West and its Disappearing Water. New York: Penguin Books.

Sapozhnikova, Y., Bawardi, O. and Schlenk, D. (2004) Pesticides and PCBs in sediments and fish from the Salton Sea, California, USA. Chemosphere, 55(6): 797-809.

Schmidt, J.J. and Matthews N. (2018) From state to system: Financialization and the water-energy-foodclimate nexus. Geoforum, 91(May): 151-59.

Scoville, C. (2019). Hydraulic society and a 'stupid little fish': Toward a historical ontology of endangerment. Theory and Society, 48(1): 1-37.

Sinclair, T.J. (2008) The New Masters of Capital: American Bond Rating Agencies and The Politics of Creditworthiness. Ithaca, NY: Cornell University Press.

Streeck, W. (2011) The crises of democratic capitalism. New Left Review, 71: 5-29.

Walton, J. (1993) Western Times and Water Wars: State, Culture, and Rebellion in California. Berkeley, CA: University Of California Press.

Weber, M. (2002) The Protestant Ethic and the Spirit of Capitalism. Los Angeles, CA: Roxbury Publishing Company.

Worster, D. (1992) Rivers of Empire: Water, Aridity, and the Growth of the American West. Oxford: Oxford University Press. 